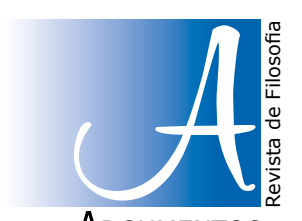

ARGUMENTOS

\title{
Nagel's reduction theory revisited
}

\author{
Teoria da redução de Nagel revisitada
}

\begin{abstract}
The aim of this paper is to develop further a model of reduction derived from Nagel's model and from the deductive-nomological model of explanation. We propose this development by examining its consistency with the history of physics, in particular, with Nagel's further account of the history of physics. In the first part, we introduce the issue of intertheoretical reduction. In the second, we examine the partial consistency of the derived D-N model of reduction with Nagel's further considerations on reduction. As a conclusion, we argue that, in agreement with Nagel's theory, the full consistency with history of science is a criterion needed for any purported theory of reduction and that the autonomy of the reducing science is to be preserved.
\end{abstract}

Keywords: Intertheoretical reduction. Nagel. Scientific explanation.

\section{RESUMO}

O objetivo deste artigo é desenvolver um modelo de redução derivado do modelo de Nagel e do modelo dedutivo-nomológico de explicação. Propomos este desenvolvimento examinando sua consistência com a história da física, em particular, com a abordagem posterior de Nagel sobre a história da física. $\mathrm{Na}$ primeira parte, introduzimos a questão da redução interteórica. $\mathrm{Na}$ segunda, examinamos a consistência parcial do modelo dedutivo-nomológico de redução com relação às considerações posteriores de Nagel sobre a redução. Em conclusão, argumentamos que, em concordância com a teoria de Nagel, uma consistência total com a história da ciência e um critério necessário para qualquer teoria da redução e que a autonomia da ciência reduzida deve ser preservada.

Palavras-chave: Redução. Nagel. Explicação científica.

\footnotetext{
* Doutor em Filosofia (UNESP). https://orcid.org/0000-0003-4658-7137
} 


\section{The issue of intertheoretical reduction in the philosophy of science}

The issue of intertheoretical reduction ${ }^{1}$ is widely debated in the philosophy of science. Such a debate concerns with the possibility of establishing a theory (which is taken to be the simplest one) from physics as the theory which reduces all others, be they the other natural sciences of even the human ones.

In this section, we discuss the deductive-nomological model of reduction (D-N model, henceforth), which is a slightly different version of the nomological principle of naturalism. According to this principle, it is expected that the laws of both human and natural sciences considered to be the high-level sciences can be reduced to the laws of physics. Physics, in such a case, is assumed to be the foundational science par excellence. Such a way of reducing sciences is D-N because philosophers of science define the explanations as a logical inference; we reduce any science to physics if, and only if, we can deduce its laws from the laws of physics.

The notion of explanation founding such reductionism was proposed by Hempel (1971). We are speaking of the D-N model of explanation in natural sciences. The source of inspiration for the theory that we examine here is the practice of reduction in physics, namely, the reduction of classical thermodynamics to kinetic theory of heat. We will discuss further the consequences of the conception of reduction mentioned afore in the next section.

Furthermore, the criticism of the D-N reduction ${ }^{2}$ is introduced and, afterwards, we will give relevance to the mathematical deduction of thermodynamical theory of heat. To begin with, let me quote Putnam (1995, p. 428), who has referred to the theory of D-N reduction as follows:

A doctrine to which most philosophers of sciences subscribe (and to which I subscribed for many years) is the doctrine that the laws of such "high-level" sciences as psychology and sociology are reducible to the laws of lowerlevel sciences - biology, chemistry - ultimately to the laws of elementary particle physics. Acceptance of this doctrine is generally identified with belief in "The Unity of Sciences" (with capitals), and rejection of it with belief in vitalism, or psychism, or, anyway, something bad.

According to the passage quoted above, it is worth noting that the definition of the naturalistic thesis of unity of sciences, which was called conventionally the "methodological naturalism" is presupposed clearly here. The characteristics of naturalism were described correctly by Feigl (1962), and correspond, in the Feigl's view, exactly to the notion of the Unity of Sciences referred to by Putnam. Therefore, we infer that the critique made by Putnam against the reductionism is a critique to the methodological naturalism as well. Putnam (1995, p. 433) summarizes his desideratum by referring to the reductionism as follows:

\footnotetext{
${ }^{1}$ The term "intertheoretical reduction" is commonly used by authors in the field of philosophy of science. This term is taken to mean the reduction relation as expressed in the issue of reduction of sciences as a way of integrating areas on the basis of a foundational theory or "primary" theory, which is commonly assumed to be physics, but might be assumed as other science such as biology or psychology.

${ }^{2}$ We will take the term "D-N reduction" to stand for "deductive-nomological reduction".
} 
In previous papers, I have argued for the hypothesis that (1) a whole human being is a Turing machine and (2) that psychological states of a human being are Turing machine states or disjunctions of Turing machine states. In this section I want to argue that this point of view was essentially wrong and that I was much in the grip of the reductionist outlook just described.

The critique of the D-N reduction model assumes the theory proposed by Nagel (1991). In accordance with his theory, which was completely inspired by the reduction of classical thermodynamics to kinetic theory of heat, the intertheoretical reducibility must satisfy certain formal conditions. To clarify them, let us consider Nagel's reduction theory as proposed by himself and also in accordance with some authors in the literature.

About Nagel's reduction concept, Kim (1998, p. 90) wrote:

Toward the end of my first lecture, I criticized Nagel's derivational model of theory reduction, especially its use in the debate over mindbody reductionism, and urged another way of looking at reduction, namely, the functional model. As I noted, Nagel's model, although its limitations have been widely noted and many variants of it have been on the scene, has dominated philosophical discussions of reduction and reductionism during the past three decades. At the heart of Nagel's model are "bridge laws", which provide the essential reductive links between the vocabulary of the theory targeted for reduction and that of the base theory, and thereby enable the derivation of the target theory from its reducer. In the philosophical applications of the model, it has been customary to assume these bridge laws to take the biconditional form, providing for each primitive predicate of the theory to be reduced with a nomologically coextensive predicate in the base theory. When the idiom in which reductionism was debated took a metaphysical turn and talk of properties became respectable again, the bridge-law requirement came to be understood as saying that each property in the domain to be reduced must be provided with a coextensive property (coextensive at least with nomic necessity) in the base domain.

Without being defenders of the Nagelian model of reduction, Bickle (2002, p. 2) introduces the topic as follows

In the spirit of logical empiricism, Nagel held that the reduction of one theory to another consists of logical derivation of the laws or principles of the former (the reduced theory $\mathrm{T}_{\mathrm{r}}$ ) from the laws or principles of the latter (the reducing or basics theory $\mathrm{T}_{\mathrm{b}}$ ). Interesting cases, where $\mathrm{T}_{\mathrm{b}}$ 's descriptive vocabulary lacks terms from that of $\mathrm{T}_{\mathrm{r}}$ ("heterogeneous" cases, as Nagel called them in 1961), various "correspondence rules" or "bridge principles" must be introduced [...].

And Brooks (1994, p. 1) also introduces the topic in this way:

Nagel slew the reductionist's dragons using the account of explanation which was orthodox amongst those working in the footsteps of the Vienna Circle. The paradigm of explanation was hypothetico-deductive. Deductive explanation was the norm in classical mechanics in the explanation of individual phenomena. In reduction, the explanation of one science by another, the laws of the primary science through being deducible from them with the assistance of bridge laws. 
All the quotations just cited refer to the logical-empiricist character of the reduction theory as it was put forward by Nagel. In what follows, I present my own take on the issue of reduction by making a more realistic account of it by means of its relation to the practice of intertheoretic reduction in theoretical physics.

\section{The D-N theory of reduction}

Now we are going to introduce one proposal of this paper: the notion of $D-N$ reduction model as applied to the case of cognitive psychology. In accordance with the definition proposed by Nagel (1961, p. 352):

[...] We must now state the formal requirements that must be satisfied for the reduction of one science to another. As has already been indicated in this chapter, a reduction is effected when the experimental laws of the secondary science (and if it has an adequate theory, its theory as well) are shown to be the logical consequences of the theoretical assumptions (inclusive of the coordinating definitions) of the primary science.

In accordance with the passage above, the conditions of deducibility, together with some pre-conditions which I will not refer here, must be satisfied. Nagel (1991) had selected the statements that designate the empirical laws and the theoretical postulates of $\mathrm{T}$ in $\mathrm{S}$. In agreement with the Kemeny-Oppenheim theory, one can express the reduction of $\mathrm{S}$ to $\mathrm{S}^{\prime}$ in the form of a deductive argument:

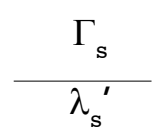

If we have the empirical laws $\lambda_{s}$, of the secondary science, we can therefore explain the phenomena in such science on the basis of the primary science. In accordance with the D-N model of explanation proposed by Hempel (1971), we have the explanation of $\mathrm{k}$ facts which are observed in the present time, $\varphi_{\mathrm{k}}{ }^{\mathrm{t}}$ by subsuming it to the $\mathrm{k}$ empirical laws $\lambda_{\mathrm{k}}$ by means of the $\mathrm{k}$ facts which are observed in the past $\varphi_{\mathrm{k}}^{\mathrm{t}-\Delta \mathrm{t}}$. Now if we relate the descriptive sentences of the corresponding facts, we have that a scientific explanation, in accordance with the explanation theory proposed by Hempel, can be described as a deductive argument of the logical form:

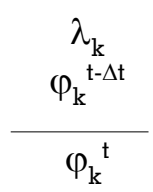

Thus, a D-N reduction of a secondary science $\mathrm{S}$ to the primary or fundamental science $\mathrm{S}^{\prime}$, in accordance with the Nagel-Hempel theory can be defined as:

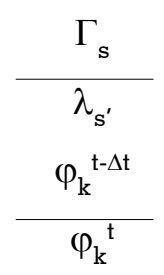


Therefore, a D-N reduction of the Cognitive Psychology to a functionalist theory of the mind can be expressed by saying that, from the empirical hypothesis of functionalism, one can deduce the empirical laws of the Cognitive Psychology. In accordance with the arguments by Putnam (1989, 1997), the reduction of the classical thermodynamics to the kinetic theory of heat is analogous to the functionalist reduction, and this reduction has been proposed in order to serve as a basis for a reduction of the Cognitive Psychology. Hence, we can write:

$\Gamma_{\text {funcionalism }}$
$\lambda_{\text {kPsychology }}$
$\frac{\varphi_{k}{ }^{\mathrm{t}-\Delta t}}{\varphi_{k}{ }^{\mathrm{t}}}$

Therefore, to 'explain' a fact $\varphi_{\mathrm{k}}$ in the Cognitive Psychology is to deduce from the set $\Gamma$ defined for the funcionalistic theory of mind. In accordance with this theory of reduction, we would obtain an explanation for the phenomena in the Cognitive Psychology. We note that Nagel (1991) did not consider the reduction of the case of Cognitive Psychology to a primary science, a reduction that would imply the dissolution of the explanatory autonomy of Cognitive Psychology (the secondary science in the D-N model of reduction) as regards physics (or as regards chemistry or even biology considered as primary sciences). According to Nagel (1960, p. 366):

\begin{abstract}
However this may be, the reduction of one science to a second - e.g. thermodynamics to statistical mechanics, or chemistry to contemporary physical theory - does not wipe out or transform into something insubstantial or 'merely apparent' the distinctions and types of behaviour which the secondary discipline recognizes. Thus, if and when the detailed physical, chemical and physiological conditions for the occurrence of headaches are ascertained, headaches will not thereby be shown to be illusory. On the contrary, if in consequence of such discoveries a portion of psychology will be reduced to another science or to a combination of other sciences, all that will have happened is that an explanation will have been found for the occurrence of headaches. But the explanation that will thus become available will be of essentially the same sort as those obtained in other areas of positive science.
\end{abstract}

The notion of explanation proposed by Nagel(1960) defines the point indicated by Putnam(1995) that, in his turn, argues against the notion of D-N reduction. The condition for deducibility is the kernel of the proposed theory of reduction. In the next section, it is identified that the condition of deducibility brings about the development of the issue of intertheoretical reduction as it is reconstructed in the logic of science.

\title{
A development of the proposed D-N model of reduction in accordance with Nagelian theory
}

In what follow, we offer a framework that is composed of theories of thermodynamics/kinetic theory of gases and of any two sciences $\mathrm{S}^{\prime}$ and $\mathrm{S}$. This 
framework sheds light to, in the simplest possible form, the D-N model as it was referred to by Nagel(1991).

\begin{tabular}{|c|c|}
\hline PHILOSOPHY OF SCIENCE & PHYSICS \\
\hline $\begin{array}{l}\text { A) Pre-conditions of the Reduction of one Science to } \\
\text { Another One: }\end{array}$ & $\begin{array}{l}\text { A) Pre-condition of Reduction of Thermodynamics to } \\
\text { Kinetic Theory: }\end{array}$ \\
\hline $\begin{array}{l}\text { A.1) Expressibility: So that } S \text { be reducible to } S^{\prime} \text { it is } \\
\text { needed that both be expressible under the form of a } \\
\text { theory T which is free, in the extent that it possible, } \\
\text { from ambiguities. T must be composed of a list of } \\
\text { statements, some of which are theoretical, others of } \\
\text { which are observational. }\end{array}$ & $\begin{array}{l}\text { A.1) Expressibility: For the reduction, we have } \\
\text { expressed the terms of the languages in the theory } \\
\text { of Thermodynamics and of the Kinetic theory of } \\
\text { heat wherein we can define the theoretical and } \\
\text { observational statements. }\end{array}$ \\
\hline $\begin{array}{l}\text { The meaning of the enunciations is defined in } \\
\text { accordance with the rules of use that are conventioned } \\
\text { in S and } \mathrm{S}^{\prime} \text {. }\end{array}$ & $\begin{array}{l}\text { We have the scientific nomenclature in which are } \\
\text { defined the physical magnitudes in accordance } \\
\text { with the system of measurement and with the } \\
\text { mathematical formalism used for relating the } \\
\text { thermodynamical and mechanical physical } \\
\text { magnitudes }\end{array}$ \\
\hline $\begin{array}{l}\mathrm{T} \text { in } \mathrm{S} \text { and in } \mathrm{S} \text { ' must be defined by the means of the } \\
\text { following set } \Gamma \text { of statements: the 'more general' the } \\
\text { theoretical postulates and 'the more particular' of } \\
\mathrm{S} \text {; empirical laws; empirical hypotheses; coordinate } \\
\text { definition or correspondence rules that associate the } \\
\text { theoretical with the observational statements of } \mathrm{T} \text { in } \\
\mathrm{S} \text { and in } \mathrm{S}^{\prime} \text {. }\end{array}$ & $\begin{array}{l}\text { In both disciplines, we have the theoretical postulates } \\
\text { that, in the case of classical thermodynamics, are } \\
\text { the phenomenological principles and, in the case } \\
\text { of the kinetic theory of heat, are hypotheses. From } \\
\text { these theoretical postulates, we deduce all the } \\
\text { particular statements of the discipline in question. } \\
\text { The more general postulates are the Newtonian laws } \\
\text { of movement. The more particular ones are the ones } \\
\text { that prevail in the mechanics of impacts of perfectly } \\
\text { elastic molecules. }\end{array}$ \\
\hline $\begin{array}{l}\text { A.2) Commensurability of } S \text { in Relation to } S^{\prime} \\
\text { The sentences of theory } T \text { of } S \text { have to have the } \\
\text { same empirical meaning of the sentences of the } \\
\text { fundamental theory } T^{\prime} \text { of } S^{\prime} \text {, so that a coordinate } \\
\text { definition that associates a theoretical sentence a } \\
\text { of } S^{\prime} \text { with an observational sentence } \underline{b} \text { of } S \text { (or vice- } \\
\text { versa)can be constructed in this way: }\end{array}$ & $\begin{array}{l}\text { A.2) Commensurability of Classical } \\
\text { Thermodynamics in relation to the Kinetic Theory } \\
\text { of Heat } \\
\text { By the means of simple definitions, we can associate } \\
\text { the phenomenological notions with the theoretical } \\
\text { notions; for example, we can associate the magnitude } \\
\text { 'temperature' } 9 \text { defined in the Classical } \\
\text { Thermodynamics to the notion 'mean molecular } \\
\text { kinetic energy' defined in the Kinetic Theory of } \\
\text { Gases by the means of the equation: }\end{array}$ \\
\hline $\mathrm{a}={ }_{\text {def. }} \mathrm{b}$ & $(\mathrm{l} / 2) \mathrm{mv}^{2}=\mathrm{k} \vartheta$ \\
\hline $\begin{array}{l}\text { B) Conditions of the Reduction of a Science to Another } \\
\text { One: }\end{array}$ & $\begin{array}{l}\text { B) Conditions of the Reduction of Thermodynamics } \\
\text { to the Kinetic Theory }{ }^{3} \text { : }\end{array}$ \\
\hline
\end{tabular}

\footnotetext{
${ }^{3}$ The deduction presented in the table is a modified deduction proposed by Pollack(1968, p. 292-296) for the kinetic theory of heat.
} 
B.1) Condition of Deduction:

The statements of the secondary science have to be logically deducible from the sentences of the primary science belonging to $\Gamma \mathrm{s}$. We can write symbolically the logical deduction as follows:

empirical law in $\mathbf{S}^{\prime}$
B.1) Deduction of the Boyle-Charles Law: We can deduce mathematically the empirical law of BoyleCharles departing from the Kinetic Theory as follows: Consider a cubical cell with the mean volume $\mathrm{x}^{3}$ and the frame of reference XYZ in which the molecules of mass $\underline{\mathrm{M}}$ which collide in the 'walls' $\mathrm{Z}_{1}$ and $\mathrm{Z}_{2}$ with the mean velocity $\mathrm{v}$ following a Brownian movement. Supposing that the collision is perfectly elastic, the total mean value of the momentum of the collision of a molecule that moves in the mean free cell of gas is then:

$$
\mathrm{mv}-(-\mathrm{mv})=2 \mathrm{mv}
$$

The mean time $\mathrm{t}$ of collision (back and forth) is:

$$
\mathrm{T}=2 \mathrm{x} / \mathrm{v}
$$

The mean force produced by the collision of each molecule is:

$$
2 \mathrm{mv} /(2 \mathrm{x} / \mathrm{v})=\mathrm{mv}^{2} / \mathrm{x}
$$

Supposing that the collisions are equiprobable in their directions and that there exist in sum $\mathrm{N}$ molecules in the frame XYZ, with their respective mean free way in the cells, the number of molecules coliding with a face in the frame XYZ is $N / 3$. Thus,

$$
\mathrm{Nmv}^{2} / 3 \mathrm{x}
$$

represents the mean force exerted upon a face of the frame XYZ. Therefore the mean pressure exerted on the area $x^{2}$ of a face of the cubical cell is:

$$
P=F / A=N m v^{2} / 3 x\left(x^{2}\right)
$$

It has been said that the mean free volume $\mathrm{V}$ of the cell, in which the gas molecule moves freely at random, is $\mathrm{x}^{3}$. We must note that $\mathrm{Nm}$ is the total mass of $\mathrm{N}$ molecules with mass $\mathrm{m}$ in a free cell of ideal gas. Therefore, the total mean pressure is calculated as:

$$
\mathrm{P}=\mathrm{mv}^{2} / 3 \mathrm{~V} \text { or } \mathrm{PV}=1 / 3 \mathrm{mv}^{2}
$$

We must now introduce the following definition or identity: the mean molecular kinetic energy is proportional to the temperature:

$$
\mathrm{K} \vartheta=1 / 2 \mathrm{mv}^{2}
$$

By replacing and eliminating $\mathrm{v}^{2}$ in the last two relations we deduce that:

$$
\mathrm{PV}=(2 / 3) \mathrm{NK} \vartheta
$$

which is the Boyle-Charles law.

Therefore, on the basis of: 1- The postulates of Newtonian mechanics, 2- The hypotheses about the molecular movement and, 3 - The definition that compares the mean kinetic energy with temperature, we deduce the Boyle-Charles law. We have, therefore, a mechanistic interpretation of the physical magnitude 'temperature'. 
c.2) Condition of Connectivity:

This condition accompanies the condition of

deducibility. The first says that if there is a term a

pertaining to the theory in the secondary science that

is not present in the theory in the primary science.

It is therefore required to introduce the theoretical

assumptions containing the term $\underline{\text { a }}$ in the primary

science, so that the deduction required by the

deducibility be possible.

On the basis of framework described above, we gather that there is a parallel that links the practice of reduction in physics and in the philosophy of science. The discussion of the history of physics supports the mathematical deduction of the Boyle-Charles Law and such a deduction is the bridge between mechanics and thermodynamics. In the sequel, we shall conclude this paper by questioning whether physics would be able to constitute the simplest reference framework for the reduction of all other special and empirical sciences.

\section{Concluding remarks}

As concluding remarks, I would like to add furthermore two points which are commonplace in the theory of reductions in contemporary philosophy of science. They are: 1- The consistency with the history of science and 2 - The autonomy of the reducing theory. Let us consider each point in the sequel.

According to the current shared assumptions in the philosophy of science, any theory of science must be consistent with the history of science (as we know since the formulation of the Lakatosian theory of science). Nagel (1998, p. 918) himself, in another paper, considers that:

[...] truth in social matters is 'historically relative': there are no universally valid analyses of social phenomena, since very such analysis is made within some distinctive social perspective which determines the meaning as well as the validity of what is said to be observed, so that those who do not share the same perspective can neither reach common conclusions about human affairs, nor significantly criticize each others' findings.

The importance of the historical factors for the understanding of the theory or reduction is pointed out by Nagel (1961, p. 361-62):

[...] the question whether a given science is reducible to another cannot in the abstract be usefully raised without reference to some particular stage of development of the two disciplines. Questions about reducibility can be profitably discussed only if they are made definite by specifying the established content at a given date of the sciences under consideration.

Moreover, Nagel clarifies and develops that much of the discussions about reduction in contemporary philosophy of science must make reference to the historical factors involved. As we read:

The irreducibility of one science to another (for example, of biology to physics) is sometimes asserted absolutely, and without temporal qualifications. In any event, arguments for such claims often appear to forget that the sciences have a history and that the reducibility (or irreducibility) 
of one science to another is contingent upon the specific theory employed by the latter discipline at some stated time. (1960, p. 363).

This confirms the recent methodology of debates in the contemporary philosophy of science. And certainly, one can apply Nagel's caveats to the discussion of intertheoretic reduction.

The second point to conclude concerns the issue of methodological autonomy of the reducing science. For Einstein, a remarkable example in the methodology of theoretical physics, classical thermodynamics is to be considered as an autonomous field of investigation of thermal phenomena. As Einstein had agued:

A theory is the more impressive the greater the simplicity of its premises is, the more different kinds of things it relates, and the more extended is its area of applicability. Therefore the deep impression which classical thermodynamics made upon me. It is the only physical theory of universal content concerning which I am convinced that, within the framework of the applicability of its basic concepts, it will never be overthrown. (1997, p. 33).

Nowadays, the theory of reduction is a base of more complex forms of theoretical constructions in science. It is well known that the classical statistical mechanics was an important reference framework for elaborating quantum mechanics and, afterwards, of quantum statistics. The analogue of reducing the quantum phenomenal with the gas phenomenal served as a basis for the formulation of the theory of light radiation and, in this context, we have had the creation of quantum statistics of Bose-Einstein and of Fermi-Dirac. In these cases, the intertheoretic reductions became more complex than those reductions that the previous theoretical accounts in the philosophy of science could describe.

\section{References}

BROOK, D.H.M. 'How to Perform a Reduction'. Philosophy and Phenomenological Research V.LIV N.4, December, 1994, p. 803-814.

EINSTEIN, A. 'Autobiographisches'. In: SCHILPP, P. A. Albert Einstein: PhilosopherScientist. Open Court, La Salle, Illinois, 1997, p.1-96.

FEIGL, H. 'Unity of science and unitary science'. In: FEIGL, H. et. al. Minnesota Studies in Philosophy of Science, Minneapolis: Minnesota University Press. 1962.

HEMPEL, C.G. Filosofia da ciência natural. São Paulo: Ed. Edusp., 1971.

KIM, J. 'Reduction and Reductionism: A New Look'. In: KIM, J. Mind in a Physical World: An Essay on the Mind-Body Problem and Mental Causation. The MIT press, Cambridge, Massachusetts. 1998.

NAGEL,T. The Structure of Science: Problems in the Logic of Scientific Explanation. Routledge \& Kegan Paul, New York. 1961.

. 'La reducción de teorias' In: La Estrutura de la Ciencia: Problemas de la Logica de la Investigación Científica. Barcelona: Ed. Paidós Básica. 1991.

. 'Issues in the Logic of Reductive Explanations'. In: CURD, M. \& COVER, J. A. Philosophy of Science: Central Issues. Norton \& Company, New York, p. 452520. 1998. 
POLLACK, H. Applied Physics. New Delhi, 1968.

PUTNAM, H. 'Brains and Behaviour'. In: MORICK, H. (ed). Challeges to Empiricism. London, Methuen \& Co., 1980. . Representation and Reality. Cambridge: MIT Press, 1989.

. Words and Life. Ed. James Conant. Cambridge, Mass. Harvard University Press, 1995.

.'Functionalism: Science or Science Fiction ?' In: MARTEL, D.M. Erneling, C.E. The Future of Cognitive Revolution. Oxford, Oxford University Press, p. 32-44, 1997.

\section{Sobre o autor}

\section{Henrique de Morais Ribeiro}

Licenciado e graduado em Filosofia pela Universidade Estadual Paulista Júlio de Mesquita Filho em 1996 e também mestre em Filosofia pela Universidade Estadual Júlio de Mesquita Filho, em 2000. É doutor em Filosofia pela Universidade de São Paulo com estágio doutoral nas Universidades de Sheffield e de Londres, King's College. Tem experiência em ensino e pesquisa acadêmicas em áreas da Epistemologia, Filosofia da Ciências Naturais, Lógica e Metafísica. Email: hdemoraisribeiro@gmail.com

Recebido em 11/04/2019

Aprovado em 12/07/2019

\section{Como referenciar esse artigo}

RIBEIRO, Henrique de Morais. Nagel's reduction theory revisited. Argumentos: Revista de Filosofia. Fortaleza, ano 11, n. 22, p. 39-48, jul.-dez. 2019. 